\title{
FACTORS AFFECTING JOB SATISFACTION OF WORKERS IN INDONESIAN CONSTRUCTION COMPANIES
}

\author{
Puti Farida Marzuki ${ }^{1}$, Hestiyani Permadi $^{2}$, Indryati Sunaryo ${ }^{3}$ \\ ${ }^{1,2}$ Faculty of Civil and Environmental Engineering, Institut Teknologi Bandung, 40132 Bandung, Indonesia \\ ${ }^{3}$ Faculty of Industrial Technology, Institut Teknologi Bandung, 40132 Bandung, Indonesia \\ E-mails: ${ }^{1}$ puti@si.itb.ac.id (corresponding author); ${ }^{2}$ hestiyani.permadi@yahoo.com; \\ ${ }^{3}$ indryati@bdg.centrin.net.id \\ Received 30 Nov. 2009; accepted 15 Feb. 2011
}

\begin{abstract}
This paper describes the influence of job characteristics, rewards, relations with superiors, relations with coworkers, and fulfillment of higher order needs, as job facets, on the job satisfaction of workers in Indonesian construction companies. A questionnaire survey was conducted in Jakarta (the capital city) and Bandung (one of Indonesia's major cities). The results revealed that workers in different occupational groups and managerial positions perceive differently the conditions of job facets and that there are different levels of job satisfaction among different categories of workers. This research indicates that workers care about the quality of their work and company's performance and that these aspects affect significantly their job satisfaction. Reward is also revealed to have an important influence on workers' job satisfaction.
\end{abstract}

Keywords: job facets, job satisfaction, workers' perception, construction companies.

\section{Introduction}

Workers in the labor intensive construction industry play a central role in the business. The performance and productivity of these workers, especially those who are in the front line such as foremen and apprentice or craft workers, determine the sustainability and competitiveness of construction companies. Previous researches revealed that worker absenteeism, high turn over, and low productivity are influenced by the motivation and job satisfaction of workers (Langford et al. 1995; Robbins 1994). Improvements of job satisfaction have a positive effect on workers' motivation, performance, and productivity (Robbins 2001; Abdel-Razek 1997, 1998).

The Indonesian construction industry is expected to absorb significantly the national workforce and enhance its contribution to the country's economic growth. Job satisfaction of workers needs to be given more attention by Indonesian construction companies to fulfill this expectation in the current globalization era. This paper identifies and analyzes the factors which affect job satisfaction of workers in Indonesian construction companies. The research includes job satisfaction measurement of workers in different management levels as well as among craft workers and is focused on actual working conditions. Data are obtained through a survey of workers in several big construction companies in two big cities, i.e. Jakarta and Bandung.

\section{Job satisfaction}

Satisfaction is seen as the last part of a chain reaction involving the motivation to satisfy a need. This chain is related to motivators that are considered as the things which induce an individual to perform. Maslow (1970) saw that human motives are based on needs that start in an ascending order from the lowest to the highest. The starting point for his human motivation theory is the needs that are called physiological drives and it is concluded that when one set of needs is satisfied it ceases to be a motivator. Through his research on motivating employees in their jobs, Herzberg (1968) found that the factors involved in producing satisfaction are separate and distinct from the factors that lead to dissatisfaction. He listed a group of satisfiers, and therefore motivators, containing factors related to job content. The other group consists of hygiene factors related to the basic human biological needs, which are not motivators but must be present, or dissatisfaction will arise.

A number of research has been dedicated to the description of job satisfaction. It is defined as a pleasure or positive emotional state resulting from a satisfactory appraisal of one's job or job experiences (Locke 1976). According to Robbins and Judge (2009), job satisfaction describes a positive feeling about a job, resulting from an evaluation of its characteristics. Job satisfaction is one of the three major job attitudes. The two other attitudes are job involvement and organizational commitment. Luthans (2004) mentioned three important dimensions of job satisfaction which include: 1) job satisfaction is an emotional response towards work situation; 2) job satisfaction is generally determined by the extent that work results fulfill expectations; 3) job satisfaction represents or reflects several related attitudes. 
The satisfaction-performance relationship has been an area of focus in the studies of satisfaction (Cox et al. 2003). The performance causes satisfaction proposition is a more recent development, but the explanation that satisfaction causes performance implies that the degree of job satisfaction felt by employees determines their performance. This reflects the popular belief that "a happy worker is a productive worker" (Cox et al. 2005). Maloney and McFillen (1985) revealed that the satisfied employee exhibits lower absenteeism and turnover and tends to file fewer grievances.

The construction industry has to deal with challenges that arise from the need to maintain a competitive workforce in order to perform well. In this regard, surveys to understand the perception of workers toward the construction industry were created in order to identify opportunities for improving the construction worksite environment (Rowings et al. 1996). Job satisfaction is the main focus of these surveys. Kazaz et al. (2008) classified work satisfaction as one of the most influential motivators among socio-psychological factors affecting construction labour productivity. Job satisfaction has also been identified as one of the factors influencing the performance of construction managers (Abdel-Razek 1997). Furthermore, improvement of employees' satisfaction is found to be one of the main categories of factors which contribute to quality improvement (Abdel-Razek 1998).

Regarding the factors that influence job satisfaction, the study conducted by Bocherding and Oglesby (1974) in the construction industry revealed that a productive job created high job satisfaction while a nonproductive job, which fell behind schedule, produced dissatisfactions at all level of the management and worker chain. This is the inverse to the relationship found in an office or factory where high job satisfaction leads to a higher productivity. Leung et al. (2008) indicated that if construction professionals have an emotional attachment to the tasks and a will to contribute their professional knowledge to the job, then job performance and job satisfaction will definitely improve in the end. In the U.S., the work of Goodrum (2003) showed that the factors influencing job satisfaction of construction workers comprised importance of income, job security, work hours, opportunity of advancement, and job importance and accomplishment over the same time period. The research revealed that craft workers in construction had a significantly higher preference for job security compared to management. Respondents in management occupations preferred important and meaningful work significantly more than craft workers. Meanwhile, both management personnel and craft workers in construction indicated important and meaningful work as the greatest job preference.

The measurement of worker job satisfaction is deemed necessary to improve performance. Robbins and Judge (2009) indicated that there are two most widely used approaches in measuring job satisfaction: 1) single global rating, consisting of a person's response to one question on his or her job satisfaction (from highly satisfied to highly dissatisfied); 2) summation score, where the key elements in a job are identified and an employ- ee's feelings about each are asked. The responses are rated on a standardized scale and added to create an overall job satisfaction score. Comparisons of the two methods indicate that one is essentially as valid as the other.

\section{Job satisfaction factors or facets}

Besides considering the previously mentioned works, the composition of job satisfaction factors studied in this research is also based on those performed by Hackman and Oldham (1980), and Langford et al. (1995), and comprises:

1) Job characteristics. Job satisfaction of workers can emanate from the nature of the work. Satisfaction can be gained when a worker has an attractive job, a chance for advancement, and a chance to take on more responsibility. A job characteristic model includes five core job dimensions that can increase motivation and job satisfaction: a) skill variety; b) task identity; c) task significance; d) autonomy; e) feed back.

2) Rewards. In general the rewards obtained by a worker can consist of intrinsic rewards and extrinsic rewards. Extrinsic rewards are given by the management to motivate workers and could be in the form of salary, promotion, etc. Meanwhile, intrinsic rewards are satisfaction gained by doing the work itself. Extrinsic rewards included in this study comprise: a) direct compensation given periodically by a company in the form of financial rewards such as salary or pay, bonus, and other incentives; b) indirect compensation in the form of insurance, leave, and other facilities; c) non financial compensation such as career advancement and improvements of working conditions.

3) Relations with superiors. Performance and satisfaction are generally positively affected when leadership can make up for deficiencies originating from workers or working conditions. The elements of relations with superiors comprises: a) communication with superiors; b) technical assistance; c) assistance in decision making; d) delegation of tasks.

4) Relations with coworkers. Cooperative coworkers have an influence on job satisfaction. An inharmonious relation with coworkers will negatively affect job satisfaction. The elements of this factor comprises: a) conflict, cooperation and synergy with coworkers; b) support from coworkers; c) communication with coworkers; d) overall relations with coworkers.

5) Higher-order needs fulfillment. In general construction workers have higher order needs such as job security, belonging, and welfare besides a mere salary improvement. Higher order needs exist in all level of worker and are beyond psychological needs.

\section{Method}

\subsection{Questionnaire}

Job satisfaction factors and their elements or variables serve as the basis for questionnaire development as shown on Table 1. 
Table 1. Scope of questionnaire

\begin{tabular}{|c|c|c|c|}
\hline Job satisfaction factor & Elements or variables & $\begin{array}{l}\text { Scope of questions } \\
\text { (variable description) }\end{array}$ & $\begin{array}{l}\text { Question } \\
\text { Number }\end{array}$ \\
\hline \multirow[t]{13}{*}{ Job characteristics } & \multirow[t]{2}{*}{ Skill variety } & Skill variety in each worker category & 1 and 2 \\
\hline & & Extent of skill variety needed & 3 \\
\hline & \multirow[t]{2}{*}{ Task identity } & Worker involvement in accomplishing tasks & 4 \\
\hline & & Worker responsibility & 5 \\
\hline & \multirow[t]{2}{*}{ Task significance } & Value of work with regard to company performance & 6 \\
\hline & & Contribution of work to the community & 7 \\
\hline & \multirow[t]{4}{*}{ Autonomy } & Workers' own initiative at work & 8 \\
\hline & & Dependence on manuals & 9 \\
\hline & & Management's authority at work & 10 \\
\hline & & $\begin{array}{l}\text { Opportunity to give suggestions and } \\
\text { participate in decision making }\end{array}$ & 11 \\
\hline & \multirow[t]{3}{*}{ Feedback } & Self evaluation on work performance & 12 \\
\hline & & Feedback from superiors & 13 \\
\hline & & Feedback from coworkers & 14 \\
\hline \multirow[t]{11}{*}{ Rewards } & \multirow[t]{4}{*}{ Direct compensation } & Fixed salary & 15 \\
\hline & & End of contract payment & 16 \\
\hline & & Bonus availability & 17 \\
\hline & & Allowance availability & 18 \\
\hline & \multirow[t]{3}{*}{ Indirect compensation } & Worker insurance & 19,23 \\
\hline & & Pension programs & 20,21 \\
\hline & & Opportunity to take a leave & 22 \\
\hline & \multirow[t]{4}{*}{$\begin{array}{l}\text { Non financial } \\
\text { Compensation }\end{array}$} & Good supporting facilities & 24,25 \\
\hline & & More responsibility at work & 26 \\
\hline & & Career advancement & $27,28,29,30$ \\
\hline & & Skill enhancement & 31 \\
\hline \multirow[t]{4}{*}{$\begin{array}{l}\text { Relations with } \\
\text { Superiors }\end{array}$} & $\begin{array}{l}\text { Communication with } \\
\text { Superiors }\end{array}$ & $\begin{array}{l}\text { Attention paid by superiors to the needs of } \\
\text { employees. Overall relations with superiors }\end{array}$ & $32,34,38$ \\
\hline & Technical assistance & $\begin{array}{l}\text { Technical assistance and guidance, supervision } \\
\text { and control }\end{array}$ & 33,35 \\
\hline & $\begin{array}{l}\text { Assistance in decision } \\
\text { making }\end{array}$ & $\begin{array}{l}\text { Assistance from superiors in making important } \\
\text { decisions }\end{array}$ & 36 \\
\hline & Delegation of tasks & Superior's role in task delegation & 37 \\
\hline \multirow[t]{5}{*}{$\begin{array}{l}\text { Relations with } \\
\text { Coworkers }\end{array}$} & $\begin{array}{l}\text { Conflict, cooperation, and } \\
\text { synergy with coworkers }\end{array}$ & Conflict, cooperation, and synergy with coworkers & 39 \\
\hline & \multirow[t]{2}{*}{$\begin{array}{l}\text { Support from } \\
\text { Coworkers }\end{array}$} & Overall support from coworkers & 40 \\
\hline & & Assistance from coworkers & 41 \\
\hline & $\begin{array}{l}\text { Communication with } \\
\text { Coworkers }\end{array}$ & Smoothness of communication & 42 \\
\hline & $\begin{array}{l}\text { Overall relations with } \\
\text { coworkers }\end{array}$ & Overall relations with coworkers & 43 \\
\hline \multirow{3}{*}{$\begin{array}{l}\text { Higher order needs } \\
\text { Fulfillment }\end{array}$} & Job security & Long term guarantee of security & 44 \\
\hline & Belonging & $\begin{array}{l}\text { Influence of good work performance on company's } \\
\text { profit and standing }\end{array}$ & $46-51$ \\
\hline & Welfare & Welfare of workers & 45 \\
\hline
\end{tabular}

The questionnaire is administered to obtain two groups of data: 1) workers' perception of the actual conditions of work with regard to job characteristics, extrinsic rewards, relations with superiors, relations with coworkers, and higher order needs fulfillment. A score is given by each respondent for each condition ranging from 1 (very bad) to 5 (very good); 2) extent of worker job satisfaction. A five-point Likert scale, 1 (very unsatisfied) to 5 (very satisfied), is used to represent workers' level satisfaction based on their perception of the actual conditions of work. Correlation between the actual conditions of work and the level of workers' job satisfaction is ana- lyzed by applying the Kendall's $\tau$ method. A sequential stepwise approach is then used for discriminant analysis.

\subsection{Demographics of respondents}

A construction company employs permanent and temporary workers. Permanent employees or company staff has a working contract and receive permanent monthly payments. Permanent workers' occupations comprise construction management, administration, and engineering. Meanwhile, temporary workers include foremen and craft workers (craftsmen and laborers) who are paid according to the amount of work accomplished during a shorter 
period of time. Foremen as suppliers of craft workers manage the distribution of this payment. Workers in a construction company are also divided into main office staff and project staff. The main office staff's functions include top management, middle management, and firstline management.

Respondents involved in the survey consist of 56 workers of 8 important construction companies (5 stateowned and 3 private) operating in two of Indonesia's major cities (Jakarta and Bandung). Table 2 shows the profile of respondents. The whole main office staff respondents consist of permanent workers, while the project staff respondents consist of temporary workers and some permanent workers who are in charge of project management. Table 3 presents the composition of respondents.

\subsection{Validity and reliability tests}

Questionnaire validity is determined by Pearson (r) correlation coefficient and its reliability is shown by Cronbach's $\alpha$ value. SPSS program is used for this analysis. The validity analysis shows that 45 items in the questionnaire are valid ( $\mathrm{r}$ calculated $>$ " $\mathrm{r}$ table" $=0.264$ with
$5 \%$ level of significance). The reliability analysis result is shown on Table 4.

Construct validity analysis is conducted for the 5 job satisfaction factors (job characteristics, rewards, relations with superiors, relations with coworkers, and fulfillment of higher order needs). The factors' scores are the sum of their respective valid and reliable questions' scores. The construct validity analysis result is shown in Table 5. The Cronbach's $\alpha$ value is 0.6101 meaning that the 5 factors are reliable.

\section{Data analysis}

\subsection{Classification of responses}

The maximum likelihood method is used to describe the perception of each category of workers on their actual conditions of work. It is assumed that the scores of each question are normally distributed. The average score is $\mu=(\Sigma x) / n$, where $\mathrm{x}$ represents the score given by each respondent for each item in the questionnaire and $n$ is number of respondents. Table 6 describes the average score classification of question responses.

Table 2. Profile of respondents

\begin{tabular}{l|l|c|c|c}
\hline \multicolumn{2}{l}{ Category of worker } & \multicolumn{2}{c}{ Staff classification } & \multirow{2}{*}{ Total } \\
\cline { 3 - 5 } \multicolumn{2}{l|}{} & Main Office & Project & \\
\hline \multirow{2}{*}{ Permanent worker } & Top management & 4 & 0 & 4 \\
\cline { 2 - 5 } & Middle management & 9 & 2 & 11 \\
\cline { 2 - 5 } & First-line management & 11 & 7 & 18 \\
\hline Temporary worker & Foremen and craft workers & 0 & 23 & 23 \\
\hline Total & & 24 & 32 & 56 \\
\hline
\end{tabular}

Table 3. Composition of respondents

\begin{tabular}{l|c|c|c}
\hline \multirow{2}{*}{} & \multicolumn{2}{|c|}{ \% of permanent or temporary workers } & \multirow{2}{*}{$\begin{array}{c}\text { Total } \\
\%\end{array}$} \\
\cline { 2 - 4 } & Main office staff & Project staff & 100 \\
\hline Permanent worker & 72.7 & 27.3 & 100 \\
\hline Temporary worker & 0 & 100 & 100 \\
\hline
\end{tabular}

Table 4. Reliability test result (" $\mathrm{r}$ table" $=0.264$; level of significance $=5 \%$ )

\begin{tabular}{l|c|l}
\hline \multicolumn{1}{c|}{ Variable } & Alpha $(\alpha)$ & Remarks \\
\hline Job characteristics & 0.6184 & Reliable \\
\hline Rewards & 0.6085 & Reliable \\
\hline Relations with superiors & 0.3441 & Reliable \\
\hline Relations with coworkers & 0.3183 & Reliable \\
\hline Fulfillment of higher order needs & 0.6530 & Reliable \\
\hline
\end{tabular}

Table 5. Construct validity analysis result ("r table" $=0,264$, level of significance $=5 \%$ )

\begin{tabular}{l|c}
\multicolumn{1}{c|}{ Factor } & r calculated \\
\hline Job characteristics & 0.6184 \\
\hline Rewards & 0.6085 \\
\hline Relations with superiors & 0.3441 \\
\hline Relations with coworkers & 0.3183 \\
\hline Fulfillment of higher order needs & 0.6530 \\
\hline
\end{tabular}


Table 6. Average score classification of responses

\begin{tabular}{l|l|l}
\hline \multirow{2}{*}{ Factors } & \multicolumn{1}{|c}{$1 \leq$ average score $<3$ (Low) } & \multicolumn{1}{c}{$3 \leq$ average score $\leq 5$ (High) } \\
\cline { 2 - 3 } & \multicolumn{1}{|c}{ Actual condition } & \multicolumn{1}{c}{ Actual condition } \\
\hline \multirow{2}{*}{ Job characteristics } & $\begin{array}{l}\text { Low skill variety, task significance, task identi- } \\
\text { ty, autonomy, and feed back }\end{array}$ & $\begin{array}{l}\text { High skill variety, task significance, task } \\
\text { identity, autonomy, and feed back }\end{array}$ \\
\hline Rewards & Rewards are rarely or never given & Rewards are always or often given \\
\hline Relations with superiors & Mediocre or bad relations with superiors & Good relations with superiors \\
\hline Relations with co-workers & Mediocre or bad relations with co-workers & Good relations with co-workers \\
\hline Higher order needs & Low job security and worker welfare & High job security and worker welfare \\
\hline & Feeling about actual condition of work & Feeling about actual condition of work \\
\cline { 2 - 3 } & Dissatisfaction & Satisfaction \\
\hline
\end{tabular}

\subsection{Actual conditions of work and job satisfaction}

Actual conditions of work and job satisfaction is analyzed in Figs 1-6:

Permanent and temporary workers' perception (Figs 1 and 2). Temporary worker respondents' responses on actual work conditions result in lower and more scattered scores compared to those of permanent workers. Permanent worker respondents perceive their relations with their superiors and coworkers as good, and think that their work provides them with a sense of well-being and security. Meanwhile, temporary worker respondents' responses reveal that they do not receive neither fixed wages, nor retirement pension and payment at the end of their working contract. Temporary worker respondents clearly do not have career possibilities in a construction company. Lower levels of satisfaction are found among temporary worker respondents compared to those of permanent workers.

Main office and project staff's perception (Figs 3 and 4). Main office staff respondents in general give high
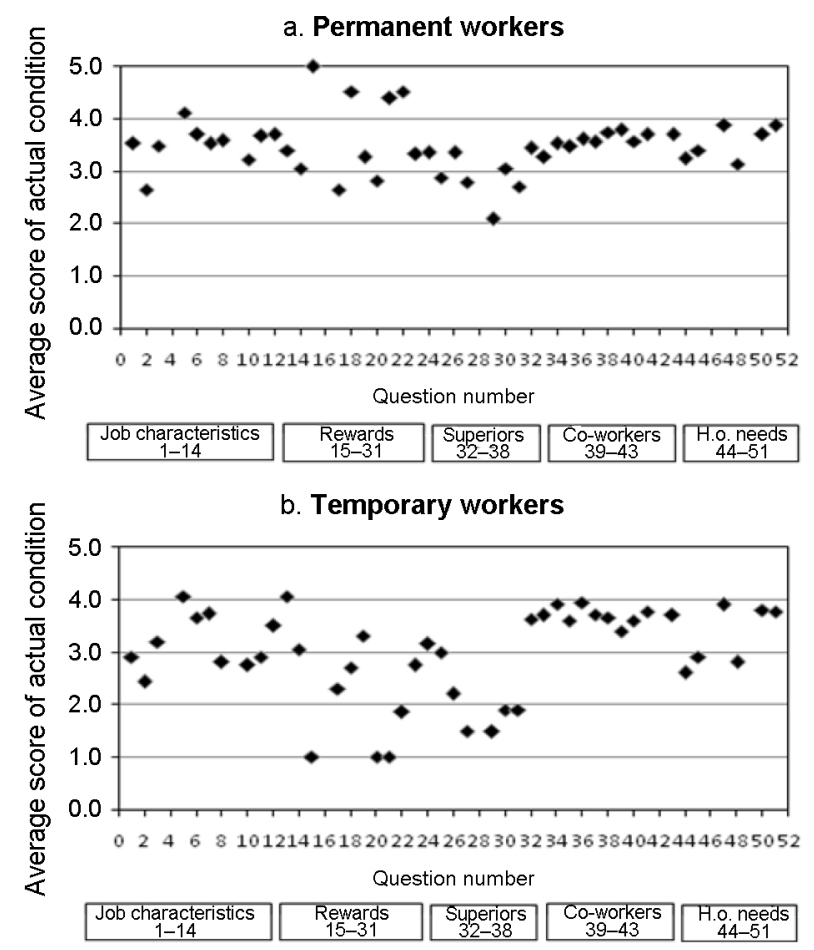

Fig. 1. Permanent and temporary worker's perception on actual work conditions
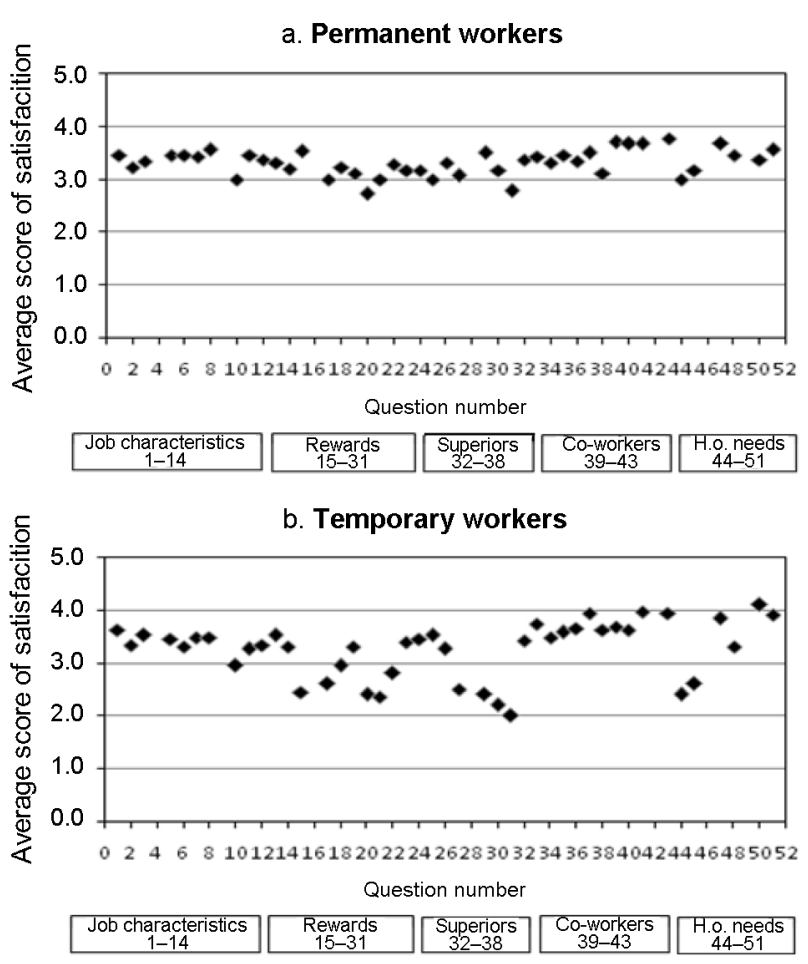

Fig. 2. Permanent and temporary worker's level of satisfaction

scores for the actual conditions of job characteristics, relations with their superiors, relations with their coworkers, and higher order needs fulfillment. Their job satisfaction is also relatively high. Meanwhile, project staff respondents reveal more varied perceptions. Project staff respondents, consisting mainly of temporary workers, give low scores for most of the elements representing the actual conditions of reward, job security and welfare, as well as autonomy in work. Low satisfaction scores are also given by these respondents for almost all elements of reward.

Top, middle, and first-line management's perception (Figs 5 and 6). Higher level management respondents have a tendency to give higher scores for actual conditions of work. Those of first-line management give low scores for 11 items regarding job characteristics and rewards. Meanwhile, from top management respondents only the actual condition regarding career advancement opportunities is given a low score. Top and middle management respondents give high satisfaction scores for almost all work conditions, while those in the first-line management level give low scores for some elements 

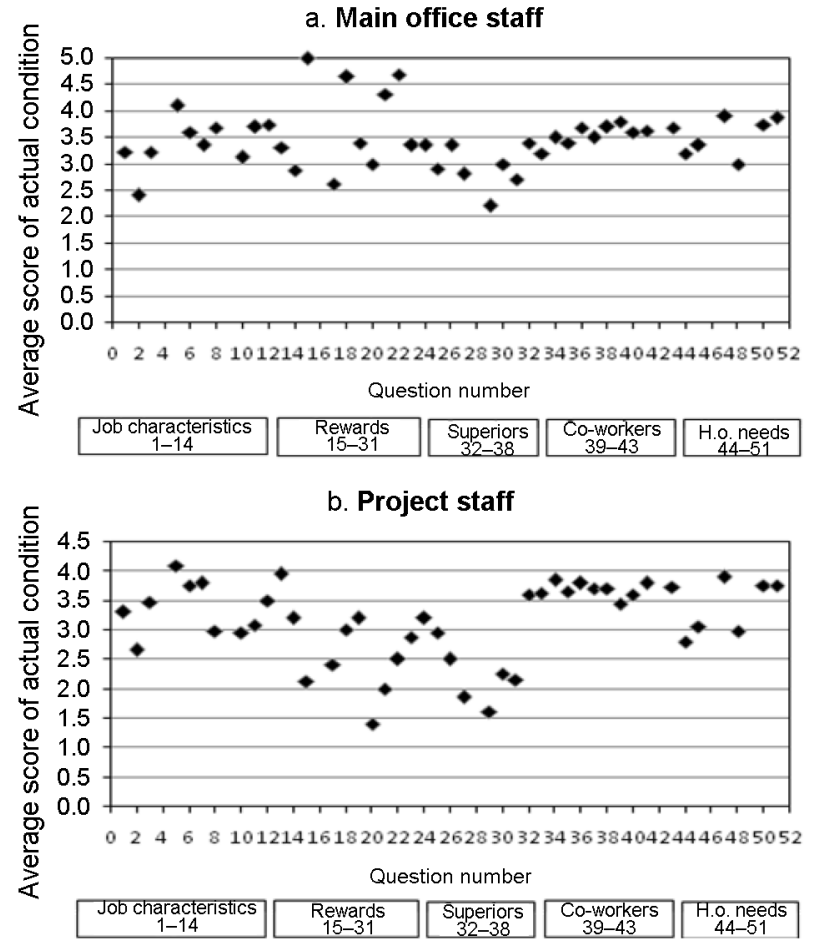

Fig. 3. Main office and project staff's perception on actual work conditions

such as autonomy, bonus, incentives, pension program, facilities, career, and training. High scores of satisfaction is given especially for relations with superiors and coworkers as well as the fulfillment of higher order needs by all levels of management.

\subsection{Job satisfaction factors score}

The maximum likelihood principle is applied in estimating each job satisfaction factor score. It is assumed that the scores of a factor's elements are uniformly distributed. The average of the scores is then the most likely observation value. An average score of $\geq 3$ is classified as high and an average score of $<3$ is classified as low. Table 7 shows actual conditions and satisfaction level scores of each job satisfaction factor. Low satisfaction is generally shown with regard to rewards by first-line management, project staff, and temporary worker respondents.
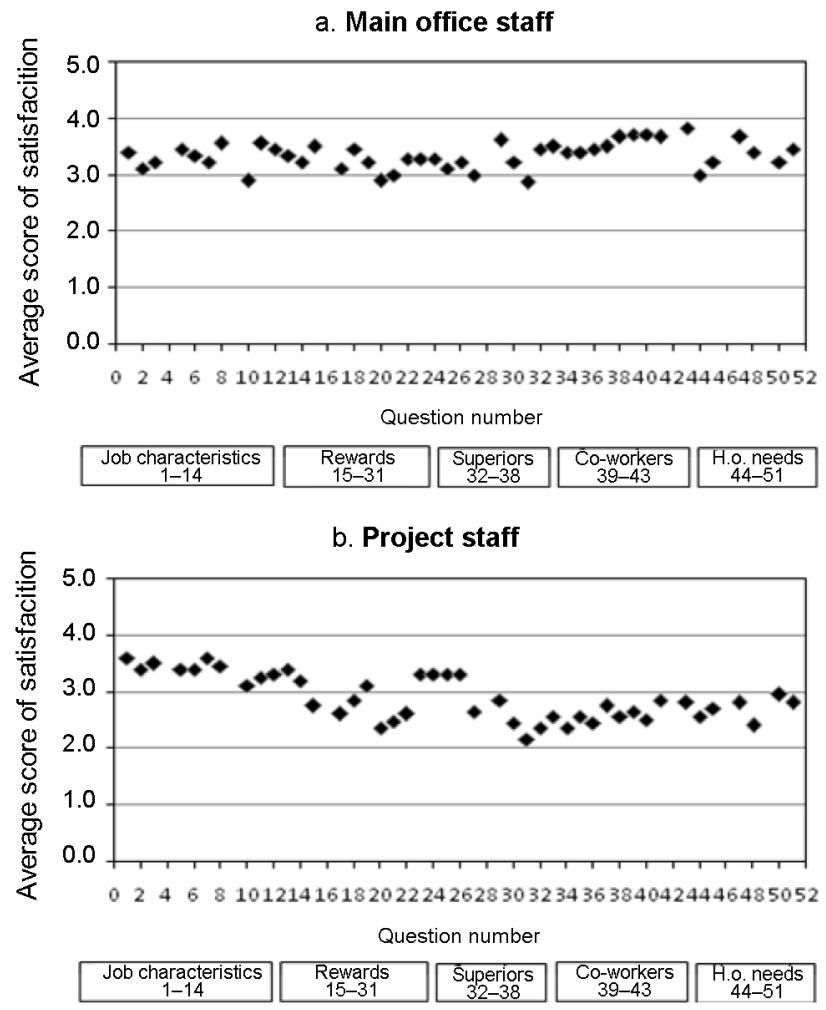

Fig. 4. Main office and project staff's level of satisfaction

Meanwhile, all other factors are perceived as satisfactory by the respondents. Table 8 indicates that there is a significant difference of satisfaction level between workers who get fixed salaries, allowances, pension, end of contract payment, and paid leave and those who don't. Table 9 presents the total satisfaction level score based on the maximum likelihood principle. Although all of the scores are relatively high it is to be noted that the weight of each element or factor is not considered in calculating the total score.

\subsection{Correlation analysis}

The Kendall's $\tau$ method is used to investigate the correlation between actual work conditions and workers' level of satisfaction. This analysis is conducted with $95 \%$ level of confidence and $5 \%$ level of significance ( $\tau>0.5$ means there is a strong relation between investigated variables).

Table 7. Actual work conditions and satisfaction scores

\begin{tabular}{|c|c|c|c|c|c|c|c|c|c|c|}
\hline \multirow{2}{*}{$\begin{array}{c}\text { Category } \\
\text { of } \\
\text { worker }\end{array}$} & \multicolumn{2}{|c|}{ Job characteristics } & \multicolumn{2}{|c|}{ Rewards } & \multicolumn{2}{|c|}{$\begin{array}{l}\text { Relations with } \\
\text { superiors }\end{array}$} & \multicolumn{2}{|c|}{$\begin{array}{l}\text { Relations with } \\
\text { co-workers }\end{array}$} & \multicolumn{2}{|c|}{$\begin{array}{l}\text { Higher order } \\
\text { Needs }\end{array}$} \\
\hline & $\begin{array}{l}\text { Actual } \\
\text { Cond. }\end{array}$ & $\begin{array}{l}\text { Satisf. } \\
\text { Level }\end{array}$ & $\begin{array}{l}\text { Actual } \\
\text { Cond. }\end{array}$ & $\begin{array}{l}\text { Satisf. } \\
\text { Level }\end{array}$ & $\begin{array}{l}\text { Actual } \\
\text { Cond. }\end{array}$ & $\begin{array}{l}\text { Satisf. } \\
\text { Level }\end{array}$ & $\begin{array}{l}\text { Actual } \\
\text { Cond. }\end{array}$ & $\begin{array}{l}\text { Satisf. } \\
\text { Level }\end{array}$ & $\begin{array}{l}\text { Act. } \\
\text { Cond. }\end{array}$ & $\begin{array}{l}\text { Satisf. } \\
\text { Level }\end{array}$ \\
\hline Permanent workers & 3.46 & 3.35 & 2.94 & 3.10 & 3.51 & 3.41 & 3.63 & 3.68 & 3.52 & 3.36 \\
\hline Temporary workers & 3.25 & 3.38 & 2.36 & 2.90 & 3.75 & 3.63 & 3.60 & 3.75 & 3.30 & 3.30 \\
\hline Main office staff & 3.36 & 3.32 & 2.98 & 3.15 & 3.49 & 3.47 & 3.63 & 3.72 & 3.52 & 3.32 \\
\hline Project staff & 3.39 & 3.40 & 2.49 & 2.89 & 3.70 & 3.52 & 3.61 & 3.71 & 3.36 & 3.39 \\
\hline Top management & 4.06 & 3.91 & 3.68 & 4.00 & 3.79 & 3.96 & 3.70 & 3.85 & 3.87 & 4.33 \\
\hline Middle management & 3.52 & 3.53 & 3.14 & 3.21 & 3.66 & 3.58 & 3.73 & 3.49 & 3.55 & 3.29 \\
\hline First-line management & 3.29 & 3.11 & 2.65 & 2.83 & 3.36 & 3.24 & 3.55 & 3.70 & 3.43 & 3.10 \\
\hline
\end{tabular}


Journal of Civil Engineering and Management, 2012, 18(3): 299-309

305

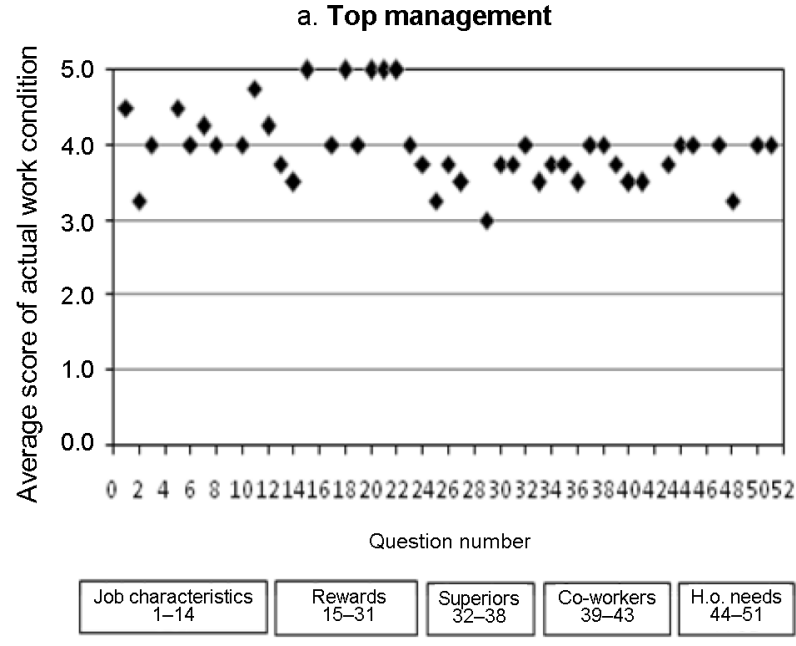

b. Middle management

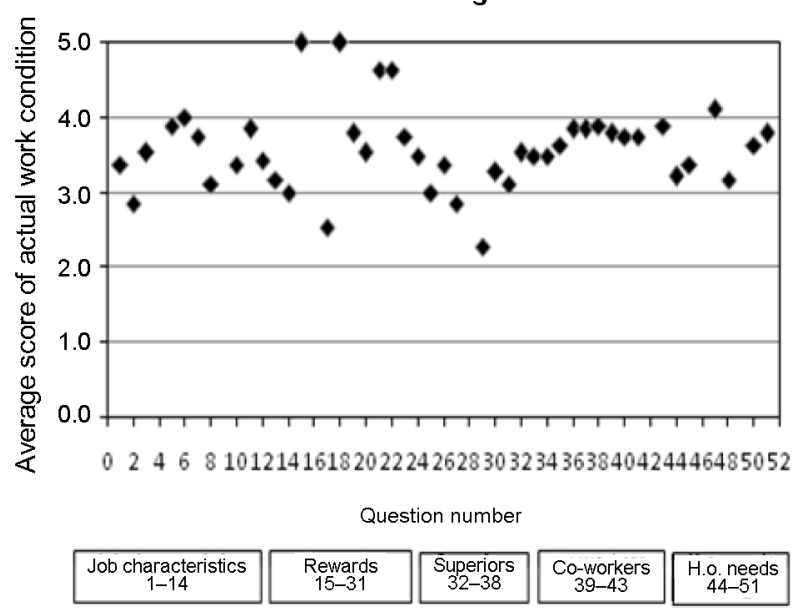

c. First-line management

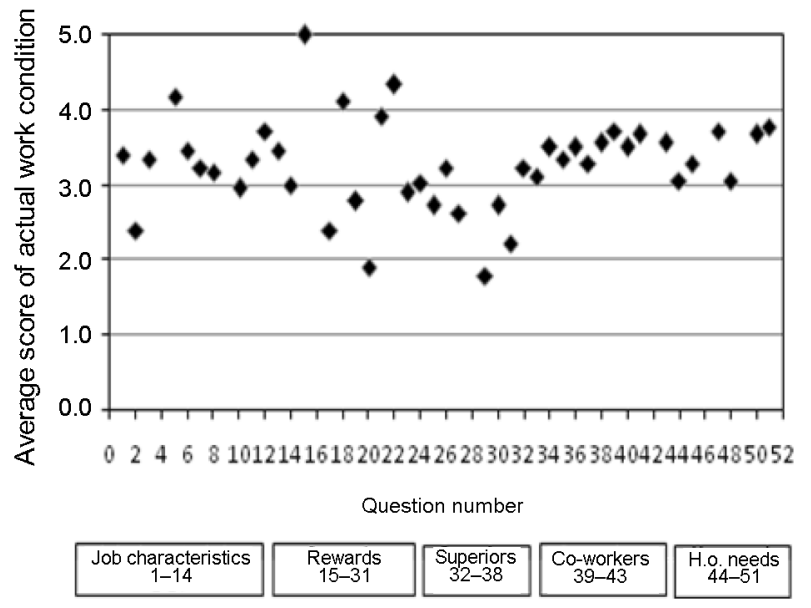

Fig. 5. Top, middle, and first-line management's perception on actual work conditions a. Top management

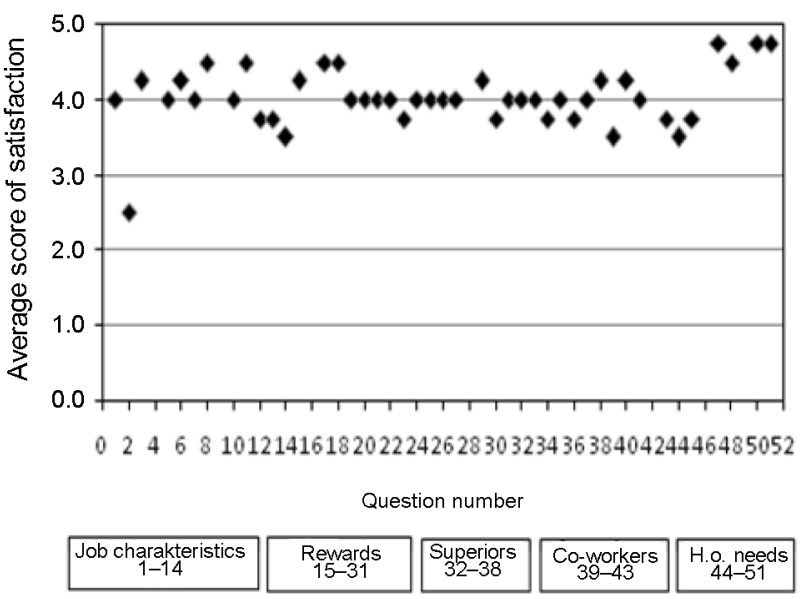

b. Middle management

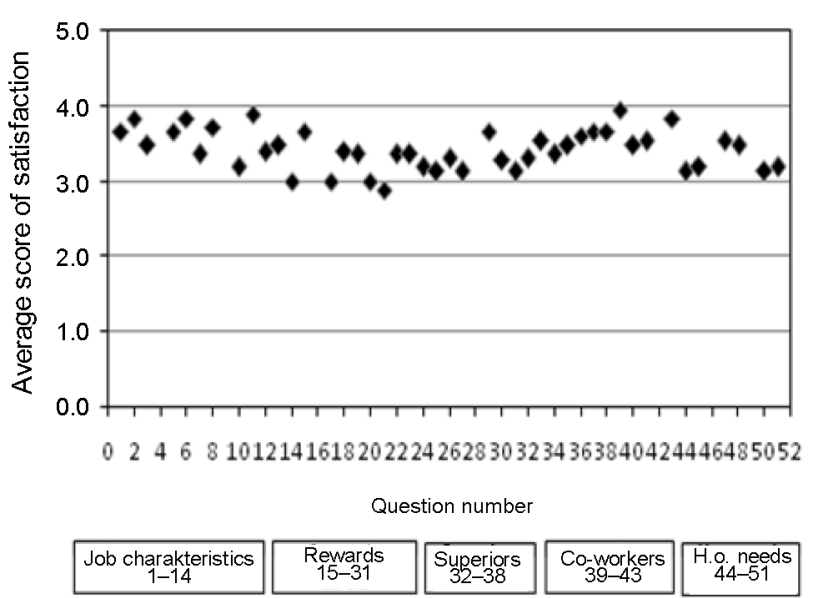

c. First-line management

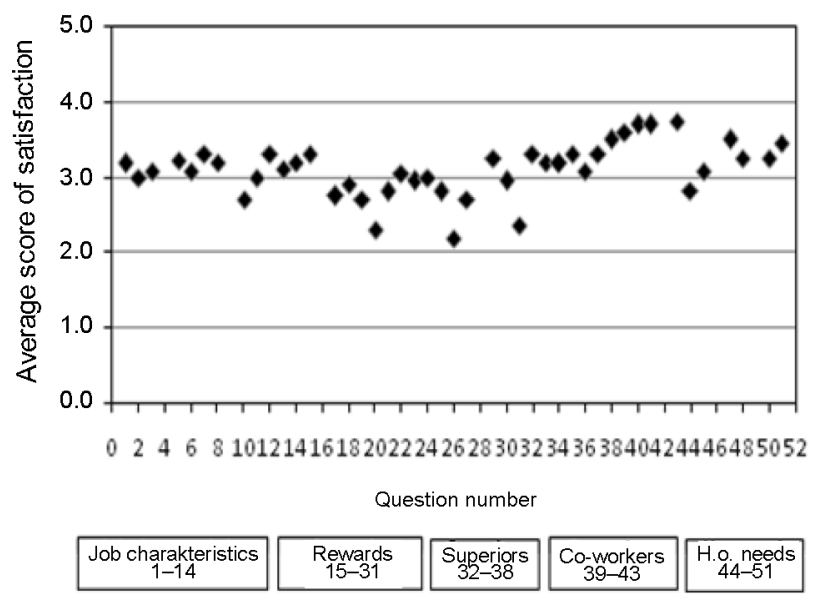

Fig. 6. Top, middle, and first-line management's level of sarisfaction 
Table 8. Response to questions on existing rewards ( $\mathrm{n}^{*}=$ number of respondents)

\begin{tabular}{|c|c|c|c|c|c|c|c|c|c|c|}
\hline & \multicolumn{2}{|c|}{ Fixed salary } & \multicolumn{2}{|c|}{ Allowances } & \multicolumn{2}{|c|}{ Pension } & \multicolumn{2}{|c|}{ End of contract payment } & \multicolumn{2}{|c|}{ Paid leave } \\
\hline & Yes & No & Yes & No & Yes & No & Yes & No & Yes & No \\
\hline $\begin{array}{l}\text { Permanent workers }(\mathrm{n}=33)^{*} \\
\text { Satisfaction score }\end{array}$ & $\begin{array}{c}33 \\
3.52\end{array}$ & 0 & $\begin{array}{c}29 \\
3.55\end{array}$ & $\begin{array}{c}4 \\
1.00\end{array}$ & $\begin{array}{c}14 \\
3.25\end{array}$ & $\begin{array}{l}19 \\
1.4\end{array}$ & $\begin{array}{c}29 \\
3.60\end{array}$ & $\begin{array}{c}4 \\
2.00\end{array}$ & $\begin{array}{c}29 \\
3.48\end{array}$ & $\begin{array}{c}4 \\
1.75\end{array}$ \\
\hline $\begin{array}{l}\text { Temporary workers }(n=23)^{*} \\
\text { Satisfaction score }\end{array}$ & 0 & $\begin{array}{c}23 \\
2.43\end{array}$ & $\begin{array}{c}13 \\
3.60\end{array}$ & $\begin{array}{c}10 \\
2.46\end{array}$ & 0 & $\begin{array}{c}23 \\
2.39\end{array}$ & 0 & $\begin{array}{c}23 \\
2.35\end{array}$ & $\begin{array}{c}5 \\
2.60\end{array}$ & $\begin{array}{c}18 \\
2.30\end{array}$ \\
\hline $\begin{array}{l}\text { Main office staff }(n=24)^{*} \\
\text { Satisfaction score }\end{array}$ & $\begin{array}{c}24 \\
3.50\end{array}$ & 0 & $\begin{array}{c}22 \\
3.68\end{array}$ & $\begin{array}{c}2 \\
1.00\end{array}$ & $\begin{array}{c}12 \\
3.75\end{array}$ & $\begin{array}{c}12 \\
2.08\end{array}$ & $\begin{array}{c}20 \\
3.30\end{array}$ & $\begin{array}{c}4 \\
1.50\end{array}$ & $\begin{array}{c}22 \\
3.75\end{array}$ & $\begin{array}{c}2 \\
1.50\end{array}$ \\
\hline $\begin{array}{l}\text { Project staff }(\mathrm{n}=32)^{*} \\
\text { Satisfaction score }\end{array}$ & $\begin{array}{c}9 \\
3.50 \\
\end{array}$ & $\begin{array}{c}23 \\
2.43 \\
\end{array}$ & $\begin{array}{c}16 \\
3.38 \\
\end{array}$ & $\begin{array}{c}16 \\
2.40 \\
\end{array}$ & $\begin{array}{l}3 \\
3\end{array}$ & $\begin{array}{c}29 \\
3.27 \\
\end{array}$ & $\begin{array}{c}8 \\
3.13 \\
\end{array}$ & $\begin{array}{c}24 \\
2.30 \\
\end{array}$ & $\begin{array}{c}7 \\
3.30 \\
\end{array}$ & $\begin{array}{c}25 \\
2.30 \\
\end{array}$ \\
\hline $\begin{array}{l}\text { Top management }(n=4)^{*} \\
\text { Satisfaction score }\end{array}$ & $\begin{array}{c}4 \\
4.25\end{array}$ & 0 & $\begin{array}{c}4 \\
4.25\end{array}$ & 0 & $\begin{array}{c}4 \\
4.00\end{array}$ & 0 & $\begin{array}{c}4 \\
4.00\end{array}$ & 0 & $\begin{array}{c}4 \\
4.00\end{array}$ & 0 \\
\hline $\begin{array}{l}\text { Middle management }(\mathrm{n}=11)^{*} \\
\text { Satisfaction score }\end{array}$ & $\begin{array}{c}11 \\
3.60\end{array}$ & 0 & $\begin{array}{c}11 \\
3.36\end{array}$ & 0 & $\begin{array}{c}7 \\
3.28\end{array}$ & $\begin{array}{c}4 \\
2.40\end{array}$ & $\begin{array}{c}10 \\
3.00\end{array}$ & $\begin{array}{c}1 \\
2.00\end{array}$ & $\begin{array}{c}11 \\
3.36\end{array}$ & 0 \\
\hline $\begin{array}{l}\text { First-line management }(\mathrm{n}=18)^{*} \\
\text { Satisfaction score }\end{array}$ & $\begin{array}{c}18 \\
3.28\end{array}$ & 0 & $\begin{array}{c}14 \\
3.43\end{array}$ & $\begin{array}{c}4 \\
1.00\end{array}$ & $\begin{array}{c}5 \\
3.75\end{array}$ & $\begin{array}{c}13 \\
1.88\end{array}$ & $\begin{array}{c}14 \\
3.20\end{array}$ & $\begin{array}{c}4 \\
1.25\end{array}$ & $\begin{array}{c}15 \\
3.30\end{array}$ & $\begin{array}{c}3 \\
1.70\end{array}$ \\
\hline
\end{tabular}

Table 9. Total job satisfaction score

\begin{tabular}{l|c}
\hline \multicolumn{1}{c|}{ Worker category } & Job satisfaction score \\
\hline Permanent workers & 3.32 \\
\hline Temporary workers & 3.25 \\
\hline Main office staff & 3.34 \\
\hline Project staff & 3.26 \\
\hline Top management & 4.02 \\
\hline Middle management & 3.41 \\
\hline First-line management & 3.12 \\
\hline
\end{tabular}

Table 10 shows the variables of actual conditions of work that have significant correlation with the satisfaction level of permanent and temporary worker respondents. The survey shows that almost all of reward variables are related to workers' job satisfaction. Career advancement is the only reward element that has no correlation with job satisfaction of temporary workers. It is noted that permanent workers who receive fixed salaries and are entitled to their pension show higher level of job satisfaction. Superiors' attention is perceived as important by permanent as well as temporary workers. Technical assistance given by superiors and supervision are especially related to the job satisfaction of temporary workers. The importance of following up and supervising labour while working is also mentioned by Kazaz et al. (2008). It is suggested to control workers periodically rather than wait close to them without leaving. Relations with coworkers, such as assistance in work, influence permanent workers' job satisfaction. Meanwhile, temporary workers seem to value more cooperative activities and the effectiveness of working together. In all worker categories, relations with coworkers are generally task oriented. The fulfillment of higher order needs in general influence permanent workers' job satisfaction while job security and quality of work are more appreciated by temporary workers.

Table 10. Actual work conditions which have significant correlation with job satisfaction (for permanent and temporary workers)

\begin{tabular}{l|l|l}
\hline \multicolumn{1}{c|}{ Factors } & \multicolumn{1}{c}{ Permanent worker } & \multicolumn{1}{c}{ Temporary worker } \\
\hline Job characteristics & Skill variety, task significance, autonomy, feedback & Task significance, autonomy \\
\hline Rewards & $\begin{array}{l}\text { Bonus, allowances, insurance, pension, pay at the end } \\
\text { of contract, leave, facilities, responsibility, career ad- } \\
\text { vancement, training }\end{array}$ & $\begin{array}{l}\text { Bonus, allowances, insurance, facilities, } \\
\text { responsibility }\end{array}$ \\
\hline Relations with superiors & $\begin{array}{l}\text { Attention, technical assistance, assistance in decision } \\
\text { making, delegation of tasks }\end{array}$ & Attention, overall relation condition \\
\hline Relations with co-workers & Assistance from co-workers & Cooperation and synergy with co-workers \\
\hline Higher order needs & Job security, belonging & Job security, belonging \\
\hline
\end{tabular}

Table 11. Actual work conditions which have significant correlation with job satisfaction (for main office and project staff)

\begin{tabular}{l|l|l}
\hline \multicolumn{1}{c|}{ Factors } & \multicolumn{1}{c}{ Main office staff } & \multicolumn{1}{c}{ Project staff } \\
\hline Job characteristics & $\begin{array}{l}\text { Skill variety, task significance, } \\
\text { autonomy, feedback }\end{array}$ & Skill variety, task significance, autonomy \\
\hline Rewards & $\begin{array}{l}\text { Bonus, allowances, insurance, pension, end } \\
\text { of contract payment, leave, facilities, responsibility, } \\
\text { career advancement, training }\end{array}$ & $\begin{array}{l}\text { Fixed salary, bonus, leave, facilities, } \\
\text { career advancement, training }\end{array}$ \\
\hline Relations with superiors & $\begin{array}{l}\text { Attention, technical assistance, assistance in decision } \\
\text { making, delegation of tasks, overall relation condition }\end{array}$ & $\begin{array}{l}\text { Attention, technical assistance, overall } \\
\text { relation condition }\end{array}$ \\
\hline Relations with co-workers & - & - \\
\hline Higher order needs & Job security, belonging & Job security, belonging, welfare \\
\hline
\end{tabular}


Table 11 shows that there is actually only a slight difference between main office and project staff with regard to the variables that influence their job satisfaction. It is noted that relations with coworkers is not perceived as significantly affecting their job satisfaction. The project staff's satisfaction, on the other hand, is more affected by elements of job characteristics. Meanwhile, sense of well-being seems to influence more the main office staff's satisfaction.

\subsection{Discriminant analysis}

The discriminant analysis is aimed to study whether there are different levels of job satisfaction among the categories of workers and then to identify the variables that cause the difference and which of the variables are to be given priority by the management. A sequential stepwise method is applied in this analysis. The test of equality of group means is conducted. The Wilks' Lambda value is used to show the ratio of the group sum of squares to the total sum of squares (Wilks' Lambda value $=1$ means that the groups tend to have the same level of job satisfaction). Meanwhile, the $\mathrm{F}$ test is performed to identify any difference among groups (significance of $\mathrm{F}>0.05$ means that there is no difference between groups). The stepwise process is started by entering the variables which have the highest $\mathrm{F}$ calculated to the discriminant equation. SPSS is used for data processing.

In analyzing permanent and temporary workers, 48 items (corresponding to questions in the questionnaire) representing the job satisfaction factors are investigated. There are a total of 56 data consisting of 33 data from permanent workers and 23 data from temporary workers. This analysis reveals that the variables differentiating the levels of satisfaction of the two groups (permanent workers and temporary workers) include salary, assistance from superiors, opportunities for career advancement, security and insurance facilities, and quality of work. A canonical correlation of 0.817 is obtained. The Wilks' Lambda gives a chi square of 56.815 with a significance value of .000 indicating that there is a significant difference between the two groups (permanent workers and temporary workers). Permanent worker respondents have a more positive attitude towards salary and career, while facilities, assistance from superiors, and quality of work are more appreciated by temporary worker respondents.

There are a total of 56 processed data in the analysis of main office staff (24 data) and project staff (32 data). This analysis reveals that the variables differentiating the levels of satisfaction of these two groups are opportunities for career advancement, quality of work, pension, significance of work, and control or supervision. A canonical correlation of 0.849 is obtained. The Wilks' Lambda gives a chi square of 46.093 with a significance value of .000 indicating that there is a significant difference between the two groups. Main office staff respondents have a more positive attitude towards the career and pension variables, while significance of work, control or supervision, and quality of work are more appreciated by project staff respondents. The summary of discriminant analysis' result is shown in Table 12.
Table 12. Summary of discriminant analysis results

\begin{tabular}{l|l}
\hline Worker category & \multicolumn{1}{c}{$\begin{array}{c}\text { Factors differentiating levels } \\
\text { of job satisfaction or positively } \\
\text { responded factors }\end{array}$} \\
\hline Permanent worker & 1) Salary; 2) Career \\
\hline Temporary workers & $\begin{array}{l}\text { 1) Assistance from superiors; } \\
\text { 2) Security; 3) Quality of work }\end{array}$ \\
\hline Main office staff & 1) Career; 2) Pension \\
\hline Project staff & $\begin{array}{l}\text { 1) Significance of work; 2) Control } \\
\text { and supervision; 3) Quality of work }\end{array}$ \\
\hline
\end{tabular}

\section{Discussion}

One of the revealing results of this research is the indication that workers care about the quality of their work as well as the company's performance and that it significantly affects their job satisfaction. This is shown by the fact that belonging, technical assistance, and cooperation with coworkers are identified as the variables affecting the job satisfaction of all categories of workers. For the company's benefit this positive situation should be enhanced through, among others, the increase of attention and acknowledgement of workers' role from the management, efforts to make work more attractive, improvement of workers' relation with their superiors or supervisors, and rewards for good performance. Work can be made more attractive by giving more attention to job characteristic variables such as autonomy and skill variety. Giving more responsibility and applying a good work rotation scheme are some of the ways to improve skill variety.

It is noted from Tables 10 and 11 that a low job satisfaction is correlated with the actual condition of reward. Based on respondents' responses, reward variables that are perceived as unsatisfactory are pension and career advancement in particular for permanent workers and main office staff. Meanwhile, the actual conditions of almost all reward variables are perceived as unsatisfactory by temporary worker and project staff respondents. These variables are positively correlated with job satisfaction which means that improvement of situations related to these variables can be expected to increase workers' satisfaction level. Similar indications are given in the work of Kazaz et al. (2008) on construction workforce in Turkey where it is found that that money as one of reward forms seems to be a satisfier and, thus, a motivator. The need for construction workers' reward improvement is also reflected in several other researches. The importance of satisfaction with financial reward as the most significant attribute of organizational effect in the context of construction industry is mentioned by Alinaitwe et al. (2009). Langford et al. (1995) stated that the construction industry has a bad record in its capacity to attract and retain high caliber labor. People's perception that the construction industry does not offer a secure career and is not attractive has formed a social barrier for young workers to enter this industry (Langford et al. 1995). Another cause is the condition of work in construction itself. The construction world is often associated with long working hours, bad condition of work safety 
and health, and uncertainties in welfare. Foremen as suppliers of temporary workers in Indonesian construction projects play an important role in determining the amount and type of reward received by craft workers. The amount of pay received by these workers usually depends on the type of work or based on the number of work days.

This research shows that composition of reward has an influence on workers' job satisfaction. A higher job satisfaction level of workers with a better pension program is revealed. Incentives can also be considered as a way to boost workers' performance.

Finally, opportunity to improve workers' skill through trainings is another condition of which the respondents express low level of satisfaction. Regarding this aspect, the work of Alinaitwe et al. (2009) on Ugandan building firms revealed construction craft workers' view that there is a general lack of training in all forms. The present research reveals that training opportunity is positively correlated with the job satisfaction level of permanent workers, main office staff, and project staff. Similar situations were also revealed among workers in other fields such as the oil and gas industry. The research conducted by Dickey et al. (2009) in the UK showed that the expectations of receiving training and promotion reduced offshore workers' intention to quit their jobs. In fact, one of the consequences of acquiring an improved skill through training is the chance for workers to get a higher salary or wage. Moreover, having skilled workers will consequently benefit contractors. According to Lill (2009), for a contractor, using multiskilled craft workers will decrease construction cost price through improving workload characteristics and a consequential shortening of the construction duration.

\section{Conclusions}

This research has indicated that job characteristics, rewards, relations with superiors, relations with coworkers, and fulfillment of higher order needs such as job security, belonging, and welfare significantly affect the job satisfaction of Indonesian construction workers. Although job satisfaction may not have a direct impact on performance, the management of a construction company can use it as a feedback in motivating its employees to achieve good work results. A special attention should be paid in offering rewards for workers' performance. It is shown in this study that the actual condition of reward is perceived as unsatisfactory by the respondents.

\section{References}

Abdel-Razek, R. H. 1997. How construction managers would like their performance to be evaluated, Journal of Construction Engineering and Management ASCE 123(3): 208-213. http://dx.doi.org/10.1061/(ASCE)0733-9364 (1997)123:3(208)

Abdel-Razek, R. H. 1998. Quality improvement in Egypt: methodology and implementation, Journal of Construction Engineering and Management ASCE 124(5): 354-360. http://dx.doi.org/10.1061/(ASCE)0733-9364(1998)124:5 (354)
Alinaitwe, H.; Mwakali, J. A.; Hansson, B. 2009. Organizational effectiveness of Ugandan building firms as viewed by craftsmen, Journal of Civil Engineering and Management 15(3): 281-288.

http://dx.doi.org/10.3846/1392-3730.2009.15.281-288

Bocherding, J. D.; Oglesby, C. H. 1974. Construction productivity and job satisfaction, Journal of the Construction Division ASCE 100(3): 413-431.

Cox, R. F.; Issa, R. R. A.; Ahrens, D. 2003. Management's perception of key performance indicators for construction, Journal of Construction Engineering and Management ASCE 129(2): 142-151. http://dx.doi.org/10.1061 /(ASCE)0733-9364(2003)129:2(142)

Cox, R. F.; Issa, R. R. A.; Koblegard, K. 2005. Management's perception of key behavioral indicators for construction, Journal of Construction Engineering and Management ASCE 131(3): 368-376. http://dx.doi.org/10.1061/ (ASCE)0733-9364(2005)131:3(368)

Dickey, H.; Watson, V.; Zangelidis, A. 2009. Job satisfaction and quit intentions of offshore workers in the UK North Sea oil and gas industry [online] MPRA [accessed 9 Febr. 2010]. Available from Internet: http://mpra.ub.unimuenchen.de/18666/.

Goodrum, P. M. 2003. Worker satisfaction and job preferences in the U.S. construction industry, in Construction Research Congress - Winds of Change: Integration and Innovation of Construction, Proceedings of Construction Research Congress.

Hackman, J. R.; Oldham, G. 1980. Work redesign. AddisonWesley Publishing Company. $330 \mathrm{p}$.

Herzberg, F. 1968. One more time: how do you motivate employees?, Harvard Business Review 46(1): 53-62.

Kazaz, A.; Manisali, E.; Ulubeyli, S. 2008. Effect of basic motivational factors on construction workforce productivity in Turkey, Journal of Civil Engineering and Management 14(2): 95-106. http://dx.doi.org/10.3846/1392-3730.2008.14.4

Langford, D.; Hancock, M. R.; Fellows, R.; Gale, A. W. 1995. Human resources management in construction $P B(\mathrm{Ciob})$. Essex: Longman Group Limited. 216 p.

Leung, M.-Y.; Chen, D.; Yu, J. 2008. Demystifying moderate variables of the interrelationships among affective commitment, job performance, and job satisfaction of construction professionals, Journal of Construction Engineering and Management ASCE 134(12): 963-971. http://dx.doi.org/10.1061/(ASCE)0733-9364(2008)134: 12(963)

Lill, I. 2009. Multiskilling in construction - a strategy for stable employment, Technological and Economic Development of Economy 15(4): 540-560.

http://dx.doi.org/10.3846/1392-8619.2009.15.540-560

Locke, E. A. 1976. The nature and causes of job satisfaction, in M. D. Dundee, L. M. Hough, et al. (Eds.). Handbook of industrial and organizational psychology. Chicago: Rand McNally, 1319-1328.

Luthans, F. 2004. Organizational behavior. $10^{\text {th }}$ Ed. McGrawHill, International Edition. $752 \mathrm{p}$.

Maloney, W. F.; McFillen, J. M. 1985. Valence of satisfaction with job outcomes, Journal of Construction Engineering and Management ASCE 111(1): 53-73. http://dx.doi. org/10.1061/(ASCE)0733-9364(1985)111:1(53)

Maslow, A. H. 1970. Motivation and personality. 2nd Ed. New York: Harper \& Row, Publishers, Inc. 369 p. 
Robbins, S. P. 1994. Essentials of organizational behavior. Prentice-Hall International Edition. 330 p.

Robbins, S. P. 2001. Organizational behavior. $9^{\text {th }}$ Ed. Prentice Hall International, Inc. 656 p.

Robbins, S. P.; Judge, T. A. 2009. Organizational behavior. New Jersey: Pearson Education, Inc. 716 p.
Rowings, J. E.; Federle, M. O.; Birkland, S. A. 1996. Characteristics of the craft workforce, Journal of Construction Engineering and Management ASCE 122(1): 83-90. http://dx.doi.org/10.1061/(ASCE)0733-9364(1996)122: $1(83)$

Puti Farida MARZUKI. Associate Professor in the Faculty of Civil and Environmental Engineering at the Institut Teknologi Bandung (ITB,), Indonesia. She is a member of the Construction Engineering and Management Research Group in ITB. Her research interests include human resource development, as well as risk and value management in the construction industry.

Hestiyani PERMADI. Received her master's degree from the Civil Engineering Department, Faculty of Civil and Environmental Engineering at the Institut Teknologi Bandung (ITB), Indonesia. Her research is focused on the Indonesian construction industry's human resource development.

Indryati SUNARYO. Associate Professor in the Faculty of Industrial Technology at the Institut Teknologi Bandung (ITB), Indonesia. She is a member of the Industrial Management Research Group in ITB. Her research interests include organizational and personnel psychology. 